\title{
Towards the Right of New Zealand Children for Free Early Childhood Education
}

\author{
Helen May \\ University of Otago \\ New Zealand
}

\begin{abstract}
This paper provides an historical and policy overview of early childhood education in New Zealand. The analysis is framed around the introduction, in July 2007, of the government's policy of 20 hours-a-week free early childhood education for three and four year old children in teacher-led early childhood programmes. This initiative extended a raft of policies intended to improve quality participation in early childhood as part of the Government's ten year Strategic Plan Pathways to the Future: Ngã Huarahi Arataki 2002-2012. A key plank of this policy is that by 2012 all adults working in teacher-led services will have teaching qualifications. Realising this has been challenging and the implementation of the ' 20 hours free' policy became a controversial media story. From age five, all New Zealand children have long had a 'right as a citizen' to free schooling. There was a level of expectation from parents that this 'right' had been extended to early childhood education. The policy was not so bold. This paper outlines the journey towards matching the rights of the school aged and preschool aged child for free education. The ' 20 hours free' policy is an important step in the process. The paper concludes with an early commentary on the issues that this policy raises in relation to: the rights of children and parents, the costs of quality, and the conflicting roles of government, community, and private enterprise in the provision of early childhood services.
\end{abstract}

Key words: early childhood, policy, rights

In July 2007, the New Zealand government introduced a policy enabling 20 hours a week free, early childhood education for three and four year olds in teacher-led centres. These include a broad range of childcare centres, termed education and care centres, home-based childcare schemes supervised by a teacher, as well as kindergartens and some Kohanga Reo-Maori language immersion centres. The policy was in addition to the government subsidy of up to

Correspondence concerning this article should be addressed to Helen May, Dean, College of Education at University of Otago, PO Box 56, Dunedin, New Zealand. Electronic mail may be sent to helen.may@otago.ac.nz.
30 hours-a-week that every licensed centre or homebased scheme receives for children, from birth to school age, attending either parent-led ${ }^{1}$ or teacher-led early childhood services. All early childhood services are non profit except for the childcare sector where there are privately owned as well as community owned centres and home-based schemes.

Implementing the ' 20 hours free' policy has been controversial. Fifty-eight percent of the education and care centres are privately owned. Providers had to opt into the scheme for their children to be eligible. Many centres' owners and managers claimed that the funding was not sufficient. The scheme would undoubtedly curb the profits of privately owned 
centres but there were also issues of quality. Some providers were concerned that the funding would not cover the level of quality previously offered by charging fees on top of the subsidy.

Parents interpreted the policy as a right for their child to a free place, and were indignant if their local centre was not opting into the scheme; if there was no place for their child in the centre of their choice, or there was no convenient early childhood service in their area. From age five all New Zealand children have long had a 'right as a citizen' to free education. There was a level of expectation that this was now extended to early childhood education. The policy was not so bold. This paper provides an historical overview of early childhood provision and policy in New Zealand outlining a journey towards matching the rights of the school and preschool child. The free early childhood policy is an important step in the process.

Amidst the current international debates and reviews concerning public policy and early childhood education (Hasan, 2007; Moss, 2007a) the New Zealand experience is of interest. Described as 'leading the wave' during the 2000s (Moss, 2007b), the New Zealand government, in partnership with the sector, has engaged in cohesive strategic planning (Ministry of Education, 2002) towards realising the visionary possibilities of the widely supported bicultural early childhood curriculum Te Whãriki (Ministry of Education, 1996) translated as a 'woven mat for all to stand on' (Reedy, 1995). Strong sector advocacy from the 1970s has ensured that early childhood issues of equity and rights have been high on any political agenda (May, 2001). Advocacy also laid the necessary foundations in the 1980s for a policy infrastructure that embedded the integration of care and education and the tenets of quality provision (Smith, 1987). Advocacy, too, was the impetus for the principles and goals of Te Whãriki in the 1990s (Carr \& May, 1999; Nuttall, 2003), that became both the 'mat' and the metaphor for teachers, parents and children from many cultures and communities to weave the diverse yet distinctive curriculum patterns of the early childhood experience in New Zealand.

\section{New Zealand Overview}

Free Kindergarten Associations were established in New Zealand from the 1890s. The government provided a small subsidy linked to emerging state interest in moral reform and child health (May, 1997). Early childhood education underwent a transformation during the second half of the twentieth century. Progressive education policies promoted preschool for three and four year olds as a benefit for children prior to school entry at age five. New early childhood services emerged to meet new needs. Each service brought a new rationale for broadening the state's interest and investment in the early years. Since 1989, government policy has incorporated the diversity of early childhood services and sought to redress earlier divides, for example between, care and education, majority and minority cultures, as well as privately owned and community operated services. Some divides have remained difficult to bridge and new divides have emerged.

New Zealand has a high level of participation in early childhood education with $98 \%$ of all four year olds and $20 \%$ of children under two years old attending a diverse range of early childhood programmes (Ministry of Education, 2007b). Nevertheless, there are disparities across locations and in the level of participation for each child. The government's 10 year Strategic Plan, Pathways to the Future: Ngã Huarahi Arataki 2002-2012 (Ministry of Education, 2002), is intended to enhance quality participation in early childhood. A new funding policy differentiates between teacher-led and parentled services (Ministry of Education, 2005). The costs of the former are recognised in the policy commitment that, by 2012, all staff working in teacher-led services will hold teaching qualifications. Implicit too, in the 
funding policy, is the acknowledgement that early childhood teachers attain pay parity with school teachers (May, 2005). Kindergarten teachers, who are employed under the State Sector Act have had pay parity since 2002. The implementation of pay parity for teachers in childcare is underway although not yet guaranteed in the private sector.

Kindergarten associations are still key providers of early childhood education but in 1992 dropped the term 'free' from their name as they began to charge fees to supplement government funding, rather than ask for 'voluntary donations'. However, the kindergarten tradition of part day 'almost free' early childhood education for three and four year old children is embedded in the New Zealand psyche, even if it not accessible for all. Parents had come to expect to pay more substantive fees for younger aged children and/or for longer hours available in childcare settings. Despite the government subsidy for all children, and childcare subsidies on fees for low income families or children with special needs, affordability remained an issue for parents.

\section{The Announcement}

In the 2004 Budget Speech in Parliament, Michael Cullen, the Minister of Finance in the Labour-led Government, promised the introduction in 2007 of 20 hours-a-week-free early childhood education for three and four year old children in teacher-led community owned services.

The announcement was a surprise, although officials had been quietly costing and negotiating a politically acceptable package for a year. Previously in 2001, the Minister of Education, Trevor Mallard, had rejected the recommendation of the Strategic Plan Working Group, "for whanau [family] and families to have a universal entitlement to a reasonable amount of free, high quality early childhood education" (Strategic Plan Working Group, 2001, p. 5). This was described by the Minister as 'blue skies thinking' and

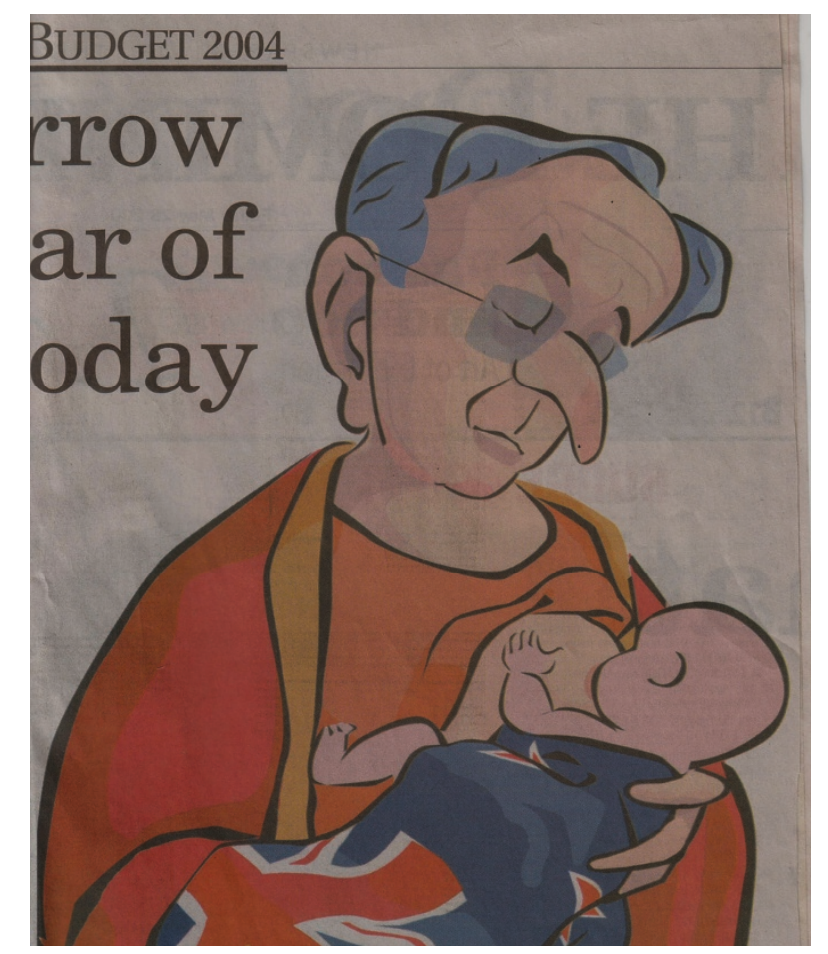

Figure 1. Budget cartoon of the Minister of Finance Michael Cullen.

'fiscally irresponsible' (Mallard, 2001). In 2002, when the Prime Minister, Helen Clark, launched the government's Strategic Plan, the recommendation for free early childhood education did not materialise. Within a year the Minister had instructed his officials to cost a proposal for free early childhood education (Ministry of Education, 2003). They did so reluctantly. ${ }^{2}$

In 2004, the '20 hours free' policy was more limited than originally conceived by the Working Group and avoided the broader issue of 'entitlement'. However, parents whose children attended private centres immediately realised that they would be disadvantaged. In the lead up to the 2005 election the issue became one of difference between the 'centreleft' Labour, and the 'centre-right' National political parties. Mallard's media headline 'Free early childhood education to go under National' (Mallard, 2005) responded to an address by the National Party's education spokesperson, Bill English, who told the 
mainly private operators attending the Early Childhood Council Annual Conference in May 2005 addressed "We oppose the 20 Hours Free policy. There's no research base for it whatsoever, it's not based in any evidence, there's no socio-economic reason for that policy." (English, 2005)

The Minister of Education's response outlined the rationale for the '20 hours free' policy as follows (Mallard, 2005):

Research shows that regular, quality and intensive early childhood education makes a positive impact on children's learning later in life. These findings are entirely consistent with other major studies undertaken in the United States and the United Kingdom. Bill English and his party have clearly decided it is much cheaper to ignore those findings and scrap the policy. This would mean around 86,000 children and their families around New Zealand will miss out. (p. 1)

The political scrapping between the 'left' and 'right' continued. In the heat of the election campaign the Prime Minister announced the extension of the policy to privately owned centres. This appealed to parents although not necessarily to the private centre owners whose finances would come under increased government scrutiny. Conversely, the National Party offered childcare tax rebates for working parents and tax cuts for everyone. The election was narrowly won by a Labour-led coalition and planning began towards implementing the ' 20 hours free' policy.

The following sections provide an overview of early childhood policy development in New Zealand framed around the shifting perceptions concerning rights, access, and provision of early childhood education. The story begins in the 1930s, concluding in the 2000s with further comment on the free early childhood policy amidst emerging debates concerning the citizenry rights of the preschool aged child.

\section{Outside State Interest: Being Fair}

In 1931, at the height of the world economic Depression, the government's small subsidy to free kindergartens was cut, and an outcry ensued. The tenor of the media campaign highlighted the 'injustice' and 'unfairness' of a 'crime' against the most 'innocent', 'poor' and 'youngest' in the education system (May, 1997, p. 150). This view of fairness and justice for the youngest and most vulnerable children was to become a persuasive argument by early childhood advocates, and still has currency in its unmet expectations.

A much quoted statement on education in 1939 from the first Labour government Minister of Education, Peter Fraser, signalled reforms that shaped New Zealand education over the remainder of the century. The statement remains a measure of the responsibilities of government in relation to the education of the citizen child (Fraser, 1939):

The government's objective, broadly expressed, is that every child: whatever his level of ability, whether he be rich or poor, whether he live in town of country, has a right as a citizen, to a free education of the kind for which he is best fitted and to the fullest extent of his powers. (p. 2) [emphasis added]

The statement, however, did not consider preschool aged children. From 1935 the first Labour government laid the foundations of a welfare state in which the interests of preschool aged children were subsumed within policies to provide safety nets for families and the priorities of infant and maternal health. World War II delayed the implementation of this education vision but heightened expectations concerning the role of the state in creating a fairer and more just society. By the end of the war the Labour government was considering a new role for the state in preschool education, promoted as a social benefit for children, a preparation for learning at school, and a support to mothers (May, 2001). 


\section{Government Policy Interest: Psychological Benefit}

New policies for the support of kindergartens with trained teachers and play centres with trained mothers were heralded (Department of Education, 1947). No government over the next 40 years pretended they could meet the demand if every three and four year old child sought a place in a preschool program. However, there was a growing expectation from parents that their children attend preschool prior to school entry. The government's interest in early childhood was framed around the perceived psychological benefits of a part-day planned educational experience, outside of the home in the company of other children and supported by trained adults.

Alongside the notion of benefits was a concern about the harm to children who attended the growing number of childcare centres (May, 2003). While professional opinion decreed childcare as potentially harmful (Bowlby, 1951), there was no government policy to either enhance or curtail its growth. In 1960 the government introduced the first childcare centre regulations, but with no funding to ensure that the children received comparable educational benefits to the children attending play centre or kindergarten.

In the 1960s, the notion of psychological benefit was broadened to include a view that some children were disadvantaged at school. The context was the presence of Maori children in schools who had rarely attended preschool, by comparison with their Pakeha (non Maori) peers who had been more often 'advantaged' by a preschool experience. Through community endeavours, a flurry of Maori preschools were established (Pewhairangi, 1983). The rhetoric was one of 'compensatory education', to 'catch up' Maori children to the same level as Pakeha children (Irwin, 1989). There was, however, no political obligation to ensure that all Maori children could access a suitable preschool.

\section{Government Caution: Issues of Equity}

During the 1970s and 1980s the language of rights became embedded in the politics of early childhood along with campaigns for women's rights, children's rights and Maori rights. Participants on a 1971 women's liberation march in Auckland demanded 'Free Mum, Free Dad, Free Me, Free Childcare (May, 2003)', challenging the policy rationale of protecting children from the possible harm of childcare. Childcare advocates argued that all children had a right to the same level of government support irrespective of the kind of early childhood service they were attending. Successive governments sidestepped the ramifications of these demands until 1989 (Meade, 1990).

The advocacy for new early childhood policy was also fuelled by demands by women for the right to participate equally in public life (May, 2001). Political interest, however, focussed on expanding the provision of part day kindergartens and play centres. By 1973, 46\% of three and four year olds were attending some kind of early childhood institution, including childcare. That demand still outstripped provision was deemed an equity issue and there was cautious government consideration of the question, 'Who gets to preschool?' (Barney, 1975). Factors of location, social class and ethnicity were cited as the key factors in a child's 'chances' to participate in early childhood education.

Liberation politics created a more radical analysis of the experience of the rights of Maori people, almost landless, and whose language and culture was besieged. From 1982, the emergence of Maori language immersion centres, Nga Kohanga Reo, became a flagship of resistance by Maori to educational integration, and a demonstration that self-determination was the only way (Jenkins \& Ka'ai, 1994). Donna Awatere (1984) rejected older notions of 'catch up' through participation: 
Kindergartens have frightened Maori people off preschool education...Maori parents won't take their children there, not because they don't want to, but because kindergartens, in particular and playcentres to a lesser extent don't meet their needs. (p. 41)

Many Maori were advocating for the right of their children to be in an early childhood institution and/or school, operated by Maori, and immersed in Maori language (Jenkins \& Ka'ai, 1994).

The Government's Before Five (Lange, 1988) reforms of 1989 were intended to redress the policy divides between the 'haves' and 'have-nots' for children, cultures, staff and services. Prime Minister, David Lange, proclaimed that early childhood would have 'equal status' with the rest of the education sector (see preface). The report Education to be More (1988) recommended equitable funding across the diverse early childhood institutions. The rights of children, women and minority groups were positioned to the fore. Anne Meade (1990, p. 96) described the impact of the reforms as enabling 'Women and children [to] gain a foot in the door'. The reality of implementing these policies in the 1990s was, however, fraught with difficulty and incomplete (Meade \& Dalli, 1992).

\section{Government Reform: Economic Agendas}

Government education policy during the 1990s was linked to economic agendas (Mitchell, 1995). The rationale of political interest was towards achieving 'quality outcomes' with measurable economic value. National curricula were justified as essential tools for ensuring high 'educational standards'. Previous 'problems' were redefined as 'risks' (Beck, 1992). Children not participating in early childhood education were perceived as a 'risk', with potential economic consequences of their not achieving the expected educational outcomes.

The earlier emphasis on rights and equity was undermined by government intentions to deregulate its older responsibilities. The sector almost lost its recently achieved, 'universal' 30 hour-a-week subsidy per child. The government promoted the idea of a targeted funding regimen calculated on financial need (Dalli, 1993). This did not materialise. Research and advocacy by scholars such as Anne Smith became a crucial tool to demonstrate the necessary elements of quality in early childhood institutions to ensure positive educational benefits for children (Smith, 1996a, 1996b).

Alternatively, the first national early childhood curriculum, Te Whãriki (Ministry of Education, 1996) recaptured the earlier focus on equity issues. The foundation principles concern the 'empowerment' of children as 'confident and competent learners' through the premise of 'responsive reciprocal relationships' (Ministry of Education, 1996, p. 9). Grounded in the rights of children, Te Whãriki acknowledges the rightful place of indigenous Maori knowledge and aspirations (Reedy, 1995) as well as the settler and migrant cultures from other lands (Nuttall, 2003). Government had intended that new national curricula across the sectors should define educational outcomes for children as a measure of accountability. Te Whariki positioned the consideration of the culture, rights and interests of children and their families as a crucial foundation for delivering 'quality outcomes' (Carr \& May, 1999).

During the 1990s the government's market-led policies favoured the establishment of profit making childcare services. In 1992, 42\% of education and care centres were privately owned. By 2001, the balance had tipped to 51\% (Ministry of Education, 2001). Many private centre owners lobbied for lesser qualifications for staff and had lower rates of pay and conditions for staff than in the community sector (Mitchell, 2002a). In 1999 a change from a Nationalled to a Labour-led government spearheaded a shift in direction. 


\section{Strategies for Change: Towards Citizenry Rights?}

The new government signalled its readiness to address outstanding issues in the sector. The role of early childhood education was on the agenda of many governments and, like New Zealand, there were economic rationales for its support (OECD, 2001). Amidst some concern at such interest, new debates were emerging. Gail Sloan Cannella (1997) wrote:

If early childhood education was reconceptualized as the pursuit of social justice for younger children, new images would emerge as the framework for action...the practice of radical democracy and the willingness to take revolutionary action. (p. 169)

Gail Sloan Cannella was attempting to deconstruct 'childhood' as being separate and distinct from 'adulthood'. This, she argued, had positioned children as second-class citizens. Gunilla Dahlberg (2000) told a New Zealand audience:

Early childhood institutions...need to be open to all families with young children. Access should not be constrained either by cost or by admission criteria, for example the employment of parents. To be so, early childhood institutions should be largely or wholly resourced and available as a right to all local children, as such being not only forums but also community institutions. (p. 8)

The notion of 'participating as a citizen' went beyond statistical measures of the benefits of participation by children in early childhood education programmes.

In New Zealand, Linda Mitchell (1999) called for 'a new debate about childhood', in which, "Early childhood institutions be conceptualised as community institutions playing an important role in fostering a democratic society. (p. 1)" She argued that early childhood policy must be framed around children's rights (Mitchell, 2002b). There was advocacy from a coalition of groups, for a 'new agenda for children' as a 'priority for policy' (Child Poverty Action Group, 2001, 2003) with particular reference to the right of all children to benefit from the country's resources. A government response was to formulate a policy Agenda for Children (Ministry for Social Development, 2002). Reconsidering early childhood policy was one part of this. A new partnership between the government and the sector would need to be forged.

The government embarked upon a 10 year strategic plan for the sector, Pathways to the Future: Ngã Huarahi Arataki 2002-2012 (Ministry of Education, 2002; Dalli $\&$ Te One, 2003). Fully realising the vision for children embedded within Te Wharriki was a key driver of the strategic plan's goals for quality participation. Another goal, 'promoting collaborative relationships', recognised the role of early childhood education (beyond the benefits for individual children) in community development.

In May 2007, the midway point in the implementation of the plan, the Ministry of Education hosted a symposium, 'Travelling the Pathways to the Future: Ngã Huarahi Arataki' (Ministry of Education, 2007a). There was a 'celebration' about the positive consequences of the strategic plan for the sector, but there was still much to evaluate particularly in relation to: a widening divide between teacher-led and parent-led services; difficulties in some locations of meeting the phasing-in of requirements for qualified teachers in centres, and the balance of the new partnership between government and the early childhood sector (Meade \& Royal-Tangaere, 2007).

The '20 hours free' policy, soon to commence, was hailed by government as a further initiative to encourage access, although the debate surrounding its implementation was becoming heated. Peter Moss, from the United Kingdom, told symposium delegates that New Zealand was 'leading the wave' of early childhood innovation. More particularly, New Zealand had 'confronted the wicked issues' with the development of an integrated and coherent national approach to funding, regulation, curriculum 
development, and qualifications (Moss, 2007b). Moss (2007b) identified further challenges towards overcoming constraints to participation. He suggested a 'universal entitlement to a free ECE service from 12 months', a re-echo of the original ideal positioned by the Strategic Plan Working Group in 2001. Within two months the actual '20 hours free' policy, if not the universal ideal, was about to start.

\section{Considering the Free Early Childhood Policy}

The immediate impact of the '20 hours free' policy was on the quarterly Consumer Price Index which reported a drop of $32.4 \%$ in the cost of early childhood to parents causing a $5.2 \%$ drop in the price of education (Statistics New Zealand, 2007). With the policy only in its first year of operation, it is too soon to fully evaluate its long term consequences. The government has been monitoring the participation rates. By February 2008, 76\% of centres including home based services were participating, benefiting $83 \%$ of all three and four year old early childhood enrolments (Ministry of Education, 2008). Only half of privately operated centres had joined the scheme.

The following snapshots of the media debate surrounding the implementation of the policy highlight some key issues regarding government policy for early childhood education as well as revealing the divided interests of the early childhood sector in New Zealand.

\section{Issues of Rights and Provision}

There was an early realisation by parents that the '20 hours free' policy was flawed if the centre their child(ren) attended had not opted into the scheme, or if they lived in small towns, rural settings or certain city suburbs where parents had little choice in the kind of service available. Unlike schools there is no public ownership of early childhood services; the provision of early childhood services is fully in the community and private domain. The NZ Herald (2007,
January 17) newspaper raised the fear early on with the headline that 'Thousands face missing out on free pre-school.' This concern was fuelled by the Early Childhood Council recommending to its private owner members majority not to participate in the scheme. Member centre parents of the 50,000 children received a pamphlet entitled, 'Early Childhood Education. Why your child might miss out?' The reason given was the level of subsidy that providers would receive from the government so that 20 hours could be free. The sentiments of rights came to the fore (Early Childhood Council, 2007):

The government promised free ECE for your child. Please act now to make sure you get what you were promised. It is only fair-no ifs, no buts, no maybes. (p. 2)

Parents from the largest city, Auckland, formed the lobby group '20 hours free please'; organised a petition to government and maintained a lively website campaign. ${ }^{3}$ Like the Council, these parents situated the problem as one of insufficient funding for centres to opt into the scheme. Conversely, the Minister of Education, Steve Maharey, saw the reluctance of some providers to join the scheme as the 'problem'. Maharey seemed to be supporting the notion of 'entitlement' that the policy did not promise, when he told the reporter for the front page story of the Sunday Star Times (2007, June 17) newspaper that 'free early childhood is about the principle of 20 hours free and right of young New Zealanders to that education' [emphasis added].

\section{Issues of Government Funding and Business Interests}

The government's dilemma was to determine a level funding that covered the real costs of providing the free hours, firstly across different locations but more contentious was the divide between community and privately owned centres. In the original 2004 policy only community owned centres were eligible. The dynamic of the private sector had been changing 
during the 2000s with big business and the sharemarket becoming politically powerful players. The increased government funding associated with the Strategic Plan stimulated a level of private sector investment that could not be matched by community organizations. Corporate chains such as $A B C$ Learning Centres, Kidicorp, and Kindercare had become significant providers with proactive strategies to buy out individual private owners and even community centres. The Australian owned ABC company is reputed to have 'made millionaires' of many New Zealand centres owners who sold out since its arrival in New Zealand in 2006 (NZ Herald, 2008, February 29). The relentless complexity of implementing the raft of Strategic Plan initiatives and the '20 hours free' policy was cited as a key reason for selling.

Deborah Brennan (2007) has been analysing the impact of business, and in particular the $A B C$ Learning Centres, on early childhood policy in Australia. She cites one private owner who states:

The childcare business is the best business I've had in my life. The government pays subsidies, the parents pay you two weeks in advance and property prices keep going up. (p. 217)

The share market, however, had its risks. In February 2008, ABC, the world's biggest publicly listed owner of childcare centres took a $60 \%$ drop in its shares overnight. The company's rapid expansion in Australia, Britain, the United States, and New Zealand was deemed the cause, sending ripples of concern amongst parents using its 116 centres in New Zealand (NZ Herald, 2008, February 29). In Australia, a concerned Federal Government promised support due to its reliance on ABC's 1095 centres for childcare provision across the country (Brisbane Times, 2008, February 27). At the time of writing the future of $A B C$ is less clear but it intends to continue its operations in New Zealand.

During its nine-year term, the New Zealand
Labour-led government had slipped in its promised resolve to support the community sector, although it has not advanced the interests of private childcare operators to the extent or level of the Australian monopoly. Linda Mitchell has tracked the differences between private and community early childhood provision in New Zealand (Mitchell, 2002a). After a media release of research data indicating lesser quality in private centres (Mitchell \& Brooking, 2007), and in the heat of the free early childhood debate, Mitchell argued (New Zealand Council for Educational Research, 2007, May 6):

If the government remains reliant on the commercial sector to ensure all children can get up to 20 hours free, then it becomes vulnerable to those services' demands for higher government funding, not to spend solely in their centre but also so they can offer private investors-who may not even be New Zealanders - a return on investment.

On the same day the Sunday Star Times (2007, May 6) reported:

\footnotetext{
Education Minister Steve Maharey issued a warning to the main commercial chains, telling them that they cannot expect to continue to make profits on the back of heavy government subsidies for childcare...with the growing emphasis on quality care there would be little scope for private operators to deliver a return to shareholders.
}

Maharey foresaw that, "the sector will over time become more and more like compulsory schooling and the chances of making a profit were almost nil." The consequence for the Minister was a reprimand from the New Zealand Commerce Commission after the share prices of these companies immediately fell, due to the Minister's comments. This was deemed to be political interference.

Kidicorp did join the '20 hours free' scheme, but only after the government conceded that legally there was nothing to stop centres, like schools, charging an 
optional fee. This has been controversial. The level of funding was also a concern to some community centres. Barnardo's childcare organization claimed that for the time being they would carry the costs of the shortfall (Barnardo's, 2007, January 19). The Auckland Kindergarten Association was a reluctant joiner of the scheme and intended to charge and 'optional fee' of 50 centres per hour to meet the shortfall. This was considerably less than Kidicorp whose 'optional fee' was $\$ 3.75$ per hour. The opposition National Party claimed, through its education spokesperson, M. P. Katherine Rich, that the '20 hours-a week-free policy' was a 'fraud' (Rich, 2007). The policy would not have eventuated under a National Government, however if elected in 2008 they are unlikely to dismantle the policy.

\section{Issues of Quality and Costs}

The Early Childhood Council described the free early childhood policy as 'dangerous' and 'the biggest threat to quality of early childhood in our generation' (NZ Herald, 2007, April 27). There is some justification that the policy can undermine quality, but the issue is also about the extent to which fees from parents and subsidies from the government should fund the actual costs of quality provision, or be used in part to enhance profits. It is ironic that the Council's statement is made on behalf of providers who have traditionally resisted any policy that could increase costs and reduce profits (Mitchell, 1995, 2002b). The strategic plan was intended as an investment in quality with the requirement that all staff in teacherled centres must be qualified teachers. The private sector had traditionally employed the minimum of qualified staff and strongly resisted the policy.

The strategic plan policies have significantly increased the costs of early childhood education. This is recognised in the government's 2005 funding model, benchmarked to the number of qualified staff employed and a collective agreement linked to pay parity (Ministry of Education, 2005). On the other hand, the new regulatory framework intended for implementation in 2008 (Ministry of Education, 2007b) has attempted to keep the costs down with little shift in the minimum staffing ratios. This is the heart of the issue because the government funding to implement the ' 20 hours free' policy is based on the regulated standard. Many centres have higher staffing ratios than the regulated standards. The private owners of the Treehouse centres termed their 'optional fee' a 'quality education surcharge'. This was intended to cover the cost of 'good staff ratios, guest speakers, a beautiful and aesthetic learning environment and provision of nutritional and sumptuous morning tea' (NZ Herald, 2007, June 17). The Consumer Price Index survey indicated that one in seven providers were charging an optional fee as of September 2007, effecting 34\% of children attending participating centres and home-based services (Statistics New Zealand, 2007).

\section{Further Debates}

This early commentary is intended to identify the issues and illustrate the polarity of the rhetoric of the '20 hours free' policy. The divides in this debate make apparent the structural tensions that underpin early childhood policy in New Zealand Balancing the multiple interests in the early childhood sector is difficult. These can be summarised as follows: (a) interests of centre providers in balancing the business of free early childhood education with the costs of quality, (b) interests of private business in protecting its profit levels, (c) interests of community services towards being the preferred provider, (d) interests of early childhood teachers in achieving full professional status and pay parity, (e) interests of parents in gaining access to free early childhood education, and (f) interests of government in increasing participation in cost effective quality early childhood.

Almost absent from the media debate was the central issue regarding the interests of children except for rhetoric about some children possibly missing out 
on services. The policy is a result of political, professional, and scholarly consensus that participation in quality early childhood is a significant benefit for children both 'here and now' in their daily life but also in the future at school and beyond. While there is still no right or entitlement for access to free early childhood education, New Zealand is inching towards this in both policy and rhetoric. This paper has outlined both the past and recent journey this has taken towards considering the rights of the preschool child 'citizen' as similarly unproblematic as the understood and undisputed rights of the school child 'citizen'.

While 'travelling the pathways to the future it will, however, be necessary to consider further the interests of children and the possibilities of what participation as a citizen child might mean in terms of pedagogy and policy. Alan Prout (2003) has argued that:

Childhood has been turned into a project. In a large part this project has been concerned with children's protection and provision rather than their social participation...that is the tendency to see them as a group to be socially shaped rather than socially included...This was a twentieth century failure that could, given the will and the resources, be remedied in this century. (p. 3)

The principles of both Te Whãriki (1996) and Pathways to the Future: Ngã Huarahi Arataki 2002-2012 (2002) demonstrate some reassurance that New Zealand has the vision for conceptualising the participating citizen child within early childhood education. Advocacy has ensured the political will and the resources. However, this case study of the ' 20 hours free' policy has highlighted the complexity of translating visionary ideals into workable policy and allowing multiple pathways and perspectives for the journey.

It is timely though in this election year (probably decided by the time of publication) that the significance of the Labour-led Government's initiatives in early childhood policy is newsworthy across the wider spectrum of New Zealand politics. In the view of Colin James, an esteemed political commentator, Labour will lose the election but in a headlined obituary on 'Labour's Legacy' he states:

When it comes time to memorialise Labour's fifth spell in office, it may be remembered most lastingly for early childhood education... Making early childhood systematic...takes us deep into a zone of policy debate: on citizens' access to participation in our economy and society. This debate is no longer just about the absence of legal or administrative impediments. It is about what constitutes genuine capacity to participate... So early childhood education is investing in infrastructure, just like building roads. It is arguably Labour's most important initiative, its biggest idea. (Otago Daily Times, 2008, February 19)

That James has understood exactly the breadth of the vision is reassuring even if, in his commentary, he concludes:

Who though it up and drove it? Trevor Mallard, back in the 1990s and then as minister. It will be his memorial too. (Otago Daily Times, 2008, February 19)

Certainly, the policy needed New Zealand's hard politician in the Cabinet and probably a female Prime Minister, Helen Clark, in power, but James was ignorant of the concerted and at times cohesive advocacy across the sector required to shift the government's interest in early childhood education from its selective and cautious gaze of earlier years (May, 2003). Jocelyn Harris reminded James of one campaigner whose 40-year academic career was instrumental:

All praise to Trevor Mallard... but let us not forget the bold and pioneering contribution of policymakers such as Prof Anne Smith...who did the research, presented the data and carried out the lobbying and 
advising so that this fundamental change in thinking about child care and education in early childhood became a reality. (Otago Daily Times, 2008, March 1)

\section{A New Platform for Advocacy}

At the time of writing the New Zealand Institute of Education-Te Riu Roa (NZEI-TRR), the organization representing primary and early childhood teachers, has called a meeting of representatives of the community organizations representing or providing early childhood education. The author has been asked to be the chair. The intent is to build broader support for the fledgling NZEI-TRR campaign 'Quality public ECE: A vision for 2020' (New Zealand Institute of Education-Te Riu Roa, 2007). This campaign is in it infancy but likely to gain momentum during the forthcoming election. NZEI-TRR is seeking consensus for a partnership across the community providers of early childhood education to oppose the growing commercial for-profit presence in the educational sector and the use of taxpayers money to enhance its profits. NZEI-TRR argues that publicly funded early childhood education is central to realising the rights of children and their families to participate in early childhood education and claim that the commercial interests of wealth accumulation conflict with the education and community values of Pathways to the Future: Ngã Huarahi Arataki 2002-2012 (New Zealand Institute for Education-Te Riu Roa, 2007).

Commercial operators are able to set up and access public money wherever they see a business opportunity. There is no mechanism to ensure that responsive, community-oriented services are universally available. Low income communities, migrant communities, Maori and Pacific families and rural communities are those most likely to miss out. (p. 2)

Winning this debate will be difficult because neither of the major political parties is inclined towards full public provision of early childhood services. Indeed, the community sector itself would be wary of ending their current independence by a full takeover. Such a campaign may divide an early childhood educational sector that has been successful in forwarding policy by working cohesively when necessary. The task of the meeting of community groups will be, in the first instance, to explore the possibilities for halting the tide of private take-overs and shifting the balance of provision back towards government support for community ownership. Convincing successive governments that public ownership of early childhood services is the essential stepping-stone towards realising the full rights of preschool children to a free early childhood education will be a long-term campaign. The New Zealand success story has been about 'travelling the pathways to the future' with a cohesive vision and policy. The present risk is that very different 'pathways' might emerge. Neglecting to support this campaign may prove detrimental to the possibility of genuine social participation of the preschool citizen child

\section{References}

Awatere, D. (1984). Maori sovereignty. Auckland, New Zealand: Broadsheet Books.

Barnardo's. (2007, January 19). Support for free early childhood [Media release]. Wellington New Zealand: Wellington.

Barney, D. (1975). Who gets to preschool? Wellington, New Zealand: New Zealand Council for Educational Research.

Beck, U. (1992). Risk society: Towards a new modernity. London: Sage.

Bowlby, J. (1951). Child care and the growth of love. London: Pelican.

Brennan, D. (2007). The ABC of child care politics. Australian Journal of Social Issues, 42(2), 213-225.

Cannella, G. S. (1997). Deconstructing early childhood education: Social justice and revolution. New York: Peter Lang. 
Carr, M., \& May, H. (1999). Te Whãriki: Curriculum voices. In H. Penn (Ed.), Early Childhood Services: Theory, policy and practice (pp. 53-73). Buckingham: Open University Press.

Child Poverty Action Group. (2001) Our children: The priority for policy. Auckland, New Zealand: Author.

Child Poverty Action Group. (2003) Our children: The priority for Auckland, New Zealand: Author.

Dahlberg, G. (2000, July). Early childhood pedagogy in a changing world. Paper presented at the NZEI-Te Rui Roa Early Childhood Millennium Conference, Wellington, New Zealand

Dalli, C. (1993). Is Cinderella back among the cinders? A review of early childhood education in the early 1990s. In New Zealand Annual Review of Education: Vol. 3 (pp. 223-254). Wellington, New Zealand: Victoria University Wellington.

Dalli, C., \& Te One, S. (2003). Early childhood education in 2002: Pathways to the future. In I. Livingston (ed.), New Zealand Annual Review of Education: Vol. 12 (pp.177-202). Wellington, New Zealand: Victoria University Wellington.

Department of Education. (1947). Report of the consultative committee on pre-school educational services. Wellington, New Zealand: Author.

Early Childhood Council. (2007). Free early childhood education. Why your child might miss out? Information for parents. Auckland, New Zealand: Author.

English, B. (2005, May). Speech notes. Contribution at the Early Childhood Council Annual Conference, Wellington, New Zealand.

Fraser, P. (1939). Report of the Department of Education Appendices to the Journal of the House of Representatives (E1). Wellington, New Zealand: Government Printer.

Hasan, A. (2007). Public policy in early childhood education and care. International Journal of Child Care and Education Policy, 1(1), 1-10.

Irwin, K. (1989). Compensatory education, Head Start and affirmative action. Implications of Maori education in New Zealand. In D. Phillips, G. Lealand \& G. McDonald (Eds.), The impact of American ideas on New Zealand's educational policy practice and thinking (pp. 33-122). Wellington, New Zealand: NZ-US Educational Foundation \& New Zealand Council for Educational Research.

Jenkins, K., \& Ka'ai, T. (1994). Maori education. A cultural experience and dilemma for the state-A new direction in Maori society. In H. Coxon, $\mathrm{K}$. Jenkins, J. Marshall \& L. Massey, (Eds.) The politics of learning and teaching in Aotearoa-New Zealand (pp. 79-148). Palmerston North, New Zealand: Dunmore Press.

Lange, D. (1988). Before five: Early childhood care and education in New Zealand. Wellington, New Zealand: Department of Education.

Mallard, T. (2001, July). Speech notes. Contribution at the book launch of 'Politics in the Playground' at the Institute for Early Childhood Studies, Victoria University of Wellington, Wellington, New Zealand.

Mallard, T. (2005, June 1). Free early childhood to go under national [Press release]. Wellington, New Zealand: Office of Minister of Education.

May, H. (1997). Discovery of early childhood. Auckland, New Zealand: Auckland University Press, Bridget Williams Books \& New Zealand Council for Educational Research.

May, H. (2001). Politics in the playground: The world of early childhood policy in postwar New Zealand. Wellington, New Zealand: Bridget Williams Books \& New Zealand Council for Educational Research.

May, H. (2002). 'Blue skies' talk in the 'playground', Delta, 54(1/2), 9-28.

May, H. (2003). Concerning women considering children: The battles of the Childcare Association 1963-2003. Wellington, New Zealand: Te Tari Puna Ora o Aotearoa-New Zealand Childcare Association.

May, H. (2005). Twenty years of consenting parties. The politics of 'working' and 'teaching' in childcare 19852005. Wellington: New Zealand Educational 
Institute-Te Riu Roa.

Meade, A. (1990). Women and children gain a foot in the door. New Zealand Women's Studies Journal, 6(1/2), 96-111.

Meade, A., \& Dalli, C. (1992). Review of the early childhood sector. In New Zealand Annual Review of Education: Vol. 1 (pp. 113-133). Wellington, New Zealand: Victoria University Wellington.

Meade, A., \& Royal-Tangaere, A. (2007, May). Travelling pathways to the future: Ngã huarahi arataki. Presented at the Early Childhood Education Symposium Proceedings of New Zealand Ministry of Education.

Ministry of Education. (1996). Te Whãriki. He Whãriki Matauranga mo nga Mokopuna o Aotearoa-Early childhood curriculum. Wellington, New Zealand: Learning Media.

Ministry of Education. (2001). Education statistics for NZ, 2001. Wellington, New Zealand: Author.

Ministry of Education. (2002). Pathways to the future: Ngã huarahi arataki. Wellington, New Zealand: Learning Media.

Ministry of Education. (2003, May). Update on funding and regulatory reviews of ECE. (FP25/07/1, LG10/ 07/1). Wellington, New Zealand: Author.

Ministry of Education. (2005). Early childhood education funding handbook. Wellington, New Zealand: Learning Media.

Ministry of Education. (2007a, May). Travelling pathways to the future: Ngã huarahi arataki. Presented at the Early Childhood Education Symposium Proceedings of New Zealand Ministry of Education.

Ministry of Education. (2007b). Update on the ECE regulatory review. Retrieved September 4, 2007, from http://www.minedu.govt.nz/index.cfm? layout $=$ index\&indexid $=882$

Ministry of Education. (2008). Free ECE monthly monitoring report. Retrieved February 4, 2008, from http://www.minedu.govt.nz/index.cfm? layout $=$ document\&doc

Ministry for Social Development. (2002). New
Zealand's agenda for children. Wellington: Ministry for Social Development.

Mitchell, L. (1995) Crossroads: Early childhood education in the mid-1990s. In New Zealand Annual Review of Education: Vol. 4 (pp. 75-92). Wellington, New Zealand: Victoria University Wellington.

Mitchell, L. (1999). A new debate about childhood. Can it make a difference? Unpublished manuscript, Victoria University of Wellington, New Zealand.

Mitchell, L. (2002a). Differences between community owned and privately owned early childhood education and care centres: A review of the evidence. Wellington, New Zealand: New Zealand Council for Educational Research .

Mitchell, L. (2002b). Currents of change: Early childhood education in 2001. In I. Livingston (ed.), New Zealand Annual Review of Education: Vol. 11 (pp. 123-143). Wellington, New Zealand: Victoria University Wellington.

Mitchell, L., \& Brooking, K. (2007). First New Zealand Council for Educational Research national survey of early childhood education services 2003-2004. Wellington, New Zealand: New Zealand Council for Educational Research.

Moss, P. (2007a). An exercise in international learning. International Journal of Child Care and Education Policy, 1(1), 11-23.

Moss, P. (2007b). Leading the wave: New Zealand in an international context. Presented at the Early Childhood Education Symposium Proceedings of New Zealand Ministry of Education.

New Zealand Institute for Education-Te Riu Roa. (2007, May 6). National survey of early childhood education [Media release]. Wellington, New Zealand: Author.

New Zealand Institute for Education-Te Riu Roa. (2007). Report to the NZEI Annual Meeting 2007: Quality public ECE-A vision for 2020. Wellington, New Zealand: Author.

Nuttall, J. (Ed.). (2003). Weaving Te Whãriki: AotearoaNew Zealand's Early Childhood Curriculum Document 
in Theory and Practice. Wellington, New Zealand: New Zealand Council for Educational Research.

OECD. (2001). Starting strong: Early childhood education and care. Paris: Author.

Pewhairangi, M. (1983). Maori self-assertion in preschool education 1961-1982. Presented at the 3rd Early Childhood Convention, Ngaruawahia, New Zealand.

Prout, A. (2003, September). Children, representation and social change. Paper presented at the European Early Childhood Research Association Conference, Glasgow, Scotland.

Reedy, T. (1995). Knowledge and power set me free. Keynote address addressed at the 6th Early Childhood Convention, Auckland, New Zealand. Rich, K. (2007, June 13). '20 hours-a-week-free policy' on Nine to Noon [Radio broadcast]. Wellington, New Zealand: New Zealand National Programme.

Smith, A. B. (1996a). Is quality a subjective or objective matter? In A. B. Smith \& N. J. Taylor (Eds.), Assessing and improving quality in early childhood centres (pp. 81-90). Dunedin, New Zealand: Children's Issues.

Smith, A. B. (1996b). The quality of childcare centres for infants in New Zealand: Monograph 4 of the New Zealand Association for Research in Education 'State-of-the-Art' series. Palmerston North, New Zealand: New Zealand Association for Research in Education.

Statistics New Zealand. (2007). Consumer price index: September 2007 quarter. Auckland, New Zealand: Author.

Strategic Plan Working Group. (2001). Consultation document for the development of the strategic plan for early childhood education. Wellington, New Zealand: Ministry of Education.

\section{Notes}

1 Parent-led services include playcentres staffed by parents, as well as some Kohanga Reo and Pacifica childcare centres that have a parental presence for licensing purposes, and/or staff who might speak Maori or a Pacific Island language but do not have [sufficient] staff with teaching qualifications.

2 The first funding proposal for the strategic plan from officials came under strong criticism from Linda Mitchell because it had backed away from universal entitlements. Mitchell had been a member of the Strategic Plan working group and on the technical working group to develop funding models. She expressed her concerns to the Minister after which the officials were instructed to go back to the 'drawing board' and consider the possibilities of free early childhood.

3 http:/ / 20hoursfree.blogspot.com 